MANAGEMENT

\title{
A comprehensive assessment of the policy of interaction between a company and its suppliers
}

\author{
O. Romashchenko, O. Barabash
}

State University of Telecommunications, Kiev, Ukraine

Corresponding author. E-mail: ol4ikv1986@gmail.com

Paper received 25.11.19; Accepted for publication 10.12.19.

\section{https://doi.org/10.31174/SEND-HS2019-214VII36-06}

\begin{abstract}
The paper developed a comprehensive system for evaluating the effectiveness of suppliers in terms of the formation of stocks of goods of a trading enterprise based on the construction of a spanning tree. Such a system makes it possible to cluster suppliers using a system of coefficients. On this basis, a specific interaction policy with each specific supplier is recommended and justified. The article also presents the results of testing the developed system at a domestic commercial enterprise.
\end{abstract}

Keywords: supplier, inventory, efficiency, system factors, clustering, spanning tree, the policy of interaction with suppliers.

Introduction. Efficiency of inventory management of commercial enterprise implicitly depends on the quality and completeness of forming inventory for resale. Given that one of the key issues of working with stocks of goods on trade enterprises should be (and is available) constantly working with suppliers in terms of evaluating the effectiveness of selected channels of purchase for a commercial enterprise. In accordance search, analysis and opinion on the effectiveness of cooperation with a particular supplier is a for effective formation of inventory for any commercial enterprise, without the fulfillment of which is impossible to talk about setting up the management of inventory. Accordingly, there is a question of assessing the evaluation of cooperation with a select number of suppliers of commercial enterprise; the logical consequence should be the formation of specific policies on specific suppliers.

Sources review. The issue of an established operation with suppliers, their selection, classification and assessment of the effectiveness of interaction for a particular commercial enterprise devoted the works of foreign and domestic scholars as O. Zuk, S.Lisova, T.Moskvitina, V.Popova, O.Uskova, V. Cherepova, J.Shraybfeder, A.Shot and so on. But still the question remains opened about the formation of specific models and methods for evaluating the effectiveness of interaction with suppliers of commercial enterprise.

In a detailed study of the literature it is clear that there is no even a single standardized system of indicators to assess the effectiveness of cooperation with suppliers to commercial enterprises, and even more impossible to talk about the recommendations on the formation of specific policy of interaction with each supplier.

Most of the sources have a simple statement of fact that the quality of marketing policy and economic performance of the commercial enterprise also depends, among many other factors, on an established and loyal cooperation with suppliers $[2,5$,$] . In this paper, O.Zuk [3] highlights the need to assess$ "the effectiveness of architectural relationships with suppliers" on certain criteria, namely, their interest in cooperation with the importance for providers of sales; cost and probability of profit of other customers. However, an open question remains exactly how these criteria can be evaluated in numerical terms, and gives the wording of the last two raises some serious questions. As more fully the issue of performance indicators to measure the performance of suppliers stated in the papers of S. Lisovoy [4].
Purpose. The aim of this paper is to develop a comprehensive system for evaluating the effectiveness of suppliers in terms of completeness and feasibility of the formation of inventory of trade enterprise with further selection the policy interaction with suppliers.

Methods. The article uses a cluster approach that divides all vendors of a trading enterprise, as well as the minimum placement tree method (still known as coverage).

Results and discussions. It should be noted that, in our opinion, among the indicators proposed by the authors, in some there is some overlap (accuracy of transport operations by maturity and risk in intervals of delivery of supplies, with any deviation and probability of incomplete delivery etc.) and the content of some general doubt (the cost of procurement of material resources through strategic alliances).

Accordingly, appears the question of active development of a comprehensive evaluation of suppliers in terms of completeness and feasibility of the formation of inventory. In order to do this, we propose to distribute all diversity of indicators that can characterize performance of a particular supplier for a particular commercial enterprise into two groups: a group that characterize the reliability of the supplier and the group that characterize its efficiency. Accordingly, the set of indicators will include the following - table 1.

By calculating the arithmetic mean value individually obtain reliability coefficient provider separately - efficiency ratio Table 2 .

The order of clustering of suppliers and construction of the spanning tree is as follows: initially selected segment between two points on the graph, the length of which is the largest, respectively, thus indirectly divided into two parts. Then much of the length of the segment distinguish these two points, the length of the interval between them is the largest of the survivors, so the whole set of data clustered on certain parts, all others must be in accordance with the recommendations for use of this method, three to six.

After breaking suppliers into clusters is raises the question of choosing the optimal strategy and policy interaction with suppliers. As for strategy, the control theory formulated following its variants: strategy of creation of strategic alliances; the strategy of vertical integration; strategy of synergistic effect on the target market; strategy comarketing; risk management strategies interaction [1].

However, as is evident from the title of the article, the relevant strategies can be recommended by a commercial enterprise, which aims to create a strategic alliance or a diversification 
plans. In the condition of the absence of such trends in the use of similar strategies to interact with suppliers in general is impossible.

Furthermore, from our point of view in terms of variability of the environment is to develop strategic plans for interaction with specific suppliers which are not producers of certain products for retail trade enterprises in general is inappropriate, especially in terms of national branching units bringing goods from producer to final consumer.

Table 1 - The recommended system of indicators to measure the effectiveness of supplier

\begin{tabular}{|c|c|c|}
\hline $\begin{array}{c}\text { Group of } \\
\text { factors }\end{array}$ & The name and symbol ratio & Procedure for calculating the coefficient \\
\hline \multirow{6}{*}{ Reliability } & $K_{1}^{R}-$ ratio of performance in terms of supply & $\begin{array}{l}\text { number of deliveries that were made in the period up to the totality of the } \\
\text { supply }\end{array}$ \\
\hline & $K_{2}^{R}$ - average life expectancy delivery & $\begin{array}{l}\text { average, over the period of days,from the date of the request until the delivery } \\
\text { of the goods to the maximum number of days' supply of goods for the period } \\
\text { analyzed supplier }\end{array}$ \\
\hline & $K_{3}^{R}$ - rate of disruption of delivery & number of deliveries that were not the fault of the supplier to supply the total \\
\hline & $\begin{array}{l}K_{4}^{R} \text { - factor the damaged products in the delivery } \\
\text { through the fault of the supplier }\end{array}$ & $\begin{array}{l}\text { number of units of goods that have been delivered from the damage caused } \\
\text { by the supplier to the total number of units of goods }\end{array}$ \\
\hline & $K_{5}^{R}$ - coefficient of branding products & $\begin{array}{l}\text { amount of trademarks, brand support are regularly conducted by the supplier } \\
\text { to charge the total amount of trademarks that are purchased retailer in the test } \\
\text { provider }\end{array}$ \\
\hline & $K_{6}^{R}$ - factor of promotion of goods & $\begin{array}{l}\text { number of trade marks on which the supplier during the billing period held a } \\
\text { promotion campaign for trade retailer plane to the total number of trademarks } \\
\text { which are purchased retailer in the test provider }\end{array}$ \\
\hline Efficiency & $K_{1}^{E}$ - coefficient of the complexity of supply & $\begin{array}{l}\text { number of units of a particular commodity groups that may have been } \\
\text { purchased and are purchased in the analyzed supplier to all trade items with } \\
\text { certain commodity groups represented in the trading floor retailer }\end{array}$ \\
\hline \multirow{5}{*}{ Efficiency } & $\begin{array}{l}K_{2}^{E} \text { - average rate of return over the period of } \\
\text { turnover in purchase prices }\end{array}$ & $\begin{array}{l}\text { amount of income from the sale of the commodities that were purchased in } \\
\text { the analyzed supplier to the trade in purchase prices for the products } \\
\text { concerned }\end{array}$ \\
\hline & $K_{3}^{E}$ - rate the quality of goods & $\begin{array}{l}\text { settlement of trade items that were subsequently identified by the poor (the } \\
\text { wrong expiration date at the time of delivery of the goods, the quantity of } \\
\text { goods that have been returned by consumers, etc.) to the total estimated trade } \\
\text { items obtained from the test provider }\end{array}$ \\
\hline & $K_{4}^{E}$ - discount rate & $\begin{array}{l}\text { number of units of goods being supplied during the billing period at a } \\
\text { discount of any type to the total quantity of goods received from the supplier } \\
\text { of the test }\end{array}$ \\
\hline & $\begin{array}{l}K_{5}^{E} \text { - coefficient opportunities for goods on a } \\
\text { commercial loan }\end{array}$ & number of units of goods to the totality of the supply of goods \\
\hline & $\begin{array}{l}K_{6}^{E} \text { - ratio of units of goods supplied on a } \\
\text { subscription basis }\end{array}$ & iits of product on a subscription to the total $\mathrm{n}$ \\
\hline
\end{tabular}

Table 2 - The values of the coefficients of reliability and efficiency of interaction with suppliers on the product line "groceries" P.E.

\begin{tabular}{|l|l|l|l|}
\multicolumn{5}{|c}{ "Berezka" } \\
\hline \multirow{2}{*}{} & List of Suppliers & Reliability & Efficiency \\
\hline 1 & S.P.E. "Ariadna" & 0,17 & 0,45 \\
\hline 2 & JSC "Byel" & 0,21 & 0,51 \\
\hline 3 & S.P.E. "Absolute 2007" & 0,31 & 0,39 \\
\hline 4 & KF LLC "Vitel" & 0,33 & 0,55 \\
\hline 5 & S.P.E "Duncan" & 0,33 & 0,66 \\
\hline 6 & TD "AVT market" & 0,34 & 0,63 \\
\hline 7 & S.P.E. "Ukrainian product" & 0,34 & 0,67 \\
\hline 8 & S.P.E. "Yashma" & 0,35 & 0,65 \\
\hline 9 & JSC "Katris" & 0,36 & 0,42 \\
\hline 10 & CHPM "Pilot" TG Argo & 0,36 & 0,44 \\
\hline 11 & S.P.E. "Nastya" & 0,36 & 0,52 \\
\hline 12 & JSC "Mekros" & 0,37 & 0,48 \\
\hline 13 & JSC "Martiprodakts & 0,38 & 0,62 \\
\hline 14 & S.E. "Defa" & 0,39 & 0,45 \\
\hline 15 & JSC "Firm Zodiac" & 0,40 & 0,48 \\
\hline 16 & TD "Success" & 0,41 & 0,53 \\
\hline 17 & ARZT "Torgservice" & 0,42 & 0,57 \\
\hline 18 & PRAT "Adamant groups" & 0,42 & 0,67 \\
\hline 19 & JSC "Dyskav" & 0,42 & 0,67 \\
\hline 20 & PRAT "Viva" & 0,44 & 0,56 \\
\hline 21 & P.E. "Eco-dong" & 0,45 & 0,45 \\
\hline 22 & S.P.E. "Liya" & 0,45 & 0,63 \\
\hline 23 & P.E. "Goodwill invest" & 0,49 & 0,66 \\
\hline & & & \\
\hline
\end{tabular}

\begin{tabular}{|l|l|l|l|}
24 & S.P.E. "Firm Yagumana" & 0,50 & 0,51 \\
\hline 25 & P.E. "Zaria" & 0,51 & 0,40 \\
\hline 26 & PRAT "Viva" & 0,51 & 0,56 \\
\hline 27 & JSC "Ukrkartoplya" & 0,55 & 0,53 \\
\hline 28 & $\begin{array}{l}\text { PAT CF "Trading House } \\
\text { Rozdon" }\end{array}$ & 0,59 & 0,47 \\
\hline 29 & KMPE "Trial" & 0,60 & 0,53 \\
\hline 30 & PRAT "Foods and goods" & 0,63 & 0,63 \\
\hline 31 & P.E. "Yuniseyl" & 0,65 & 0,57 \\
\hline
\end{tabular}

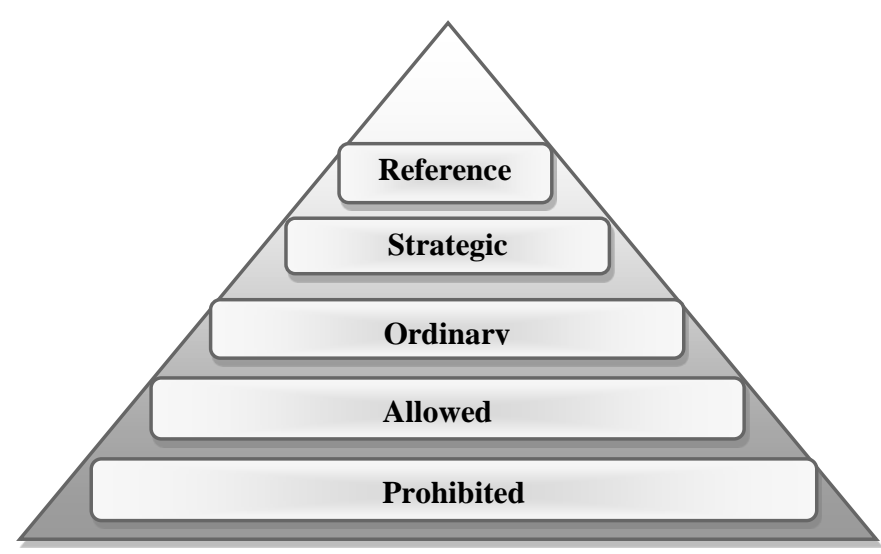

Figure 1 - Pyramid of classification suppliers [4] 
Accordingly, more appropriate, based on the above conditions is to develop a set of alternative policies interact with suppliers further by choosing from one of them, depending on the characteristics of the supplier. For this purpose should consider the developed in theory the pyramid of classification suppliers which is shown in Figure 1.

Unfortunately, in his work the author did not set out not only the criteria for each, supplier should position at some level of the pyramid - not even given the exact wording of each of the levels.

Obviously, the highest level - the reference providers - should accumulate that part of them which is most important to the enterprise, at least based on the term "reference" (which was first applied in psychology, American psychologist G. Hayman and interpreted as a kind of quality subject determined by the degree of relevance to the other entity or group of entities, including the following, which is a factor of personalization [5]. However, with such interpretation (and the other, based on the terms used, cannot be) misunderstood the question remains - what exactly have a different last and penultimate level of the pyramid? Thus, in our opinion, this pyramid is composed of four levels, and therefore all vendors are distributed into four groups - reference, ordinary, allowed and prohibited. According, the pyramid of policy interaction with suppliers is on the Figure 2.

We form clusters of four suppliers which are listed below based on policies developed by the types of interaction with suppliers.

Thus, guided by the constructed spanning tree for the studied company P.E. "Berezka" is recommended the following policy of interaction with suppliers - Figure 3

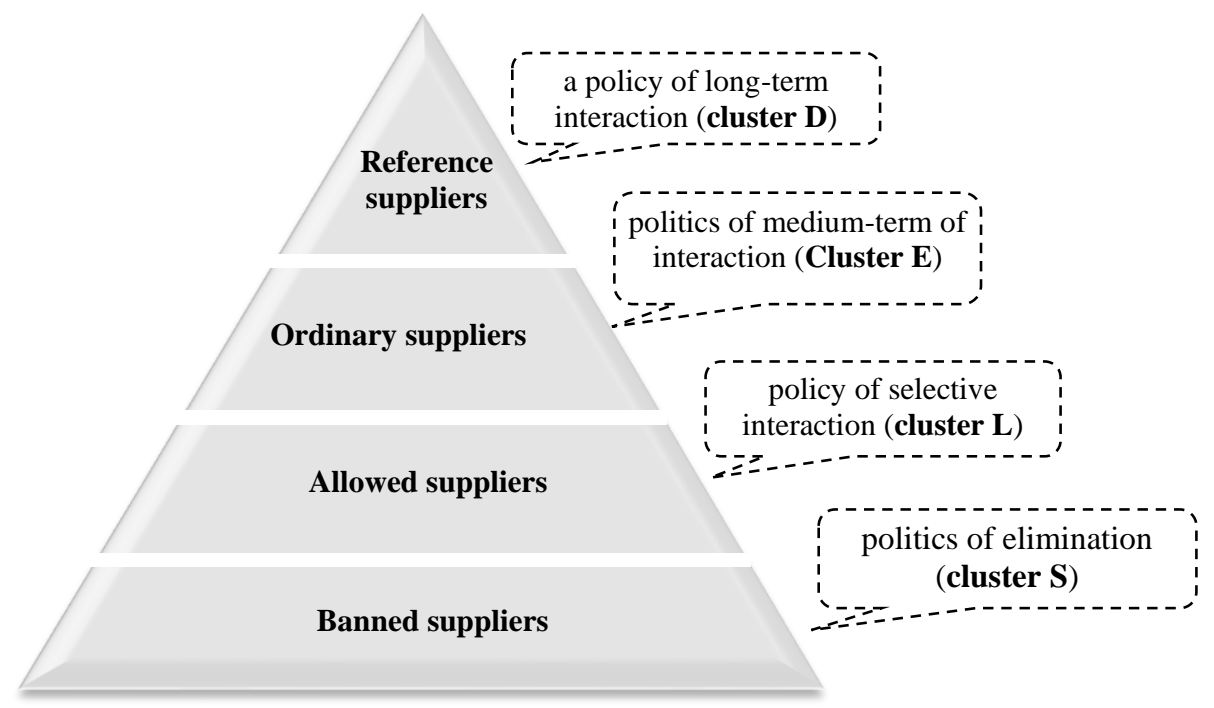

Figure 2 - Author pyramid of classification policy of interaction with suppliers

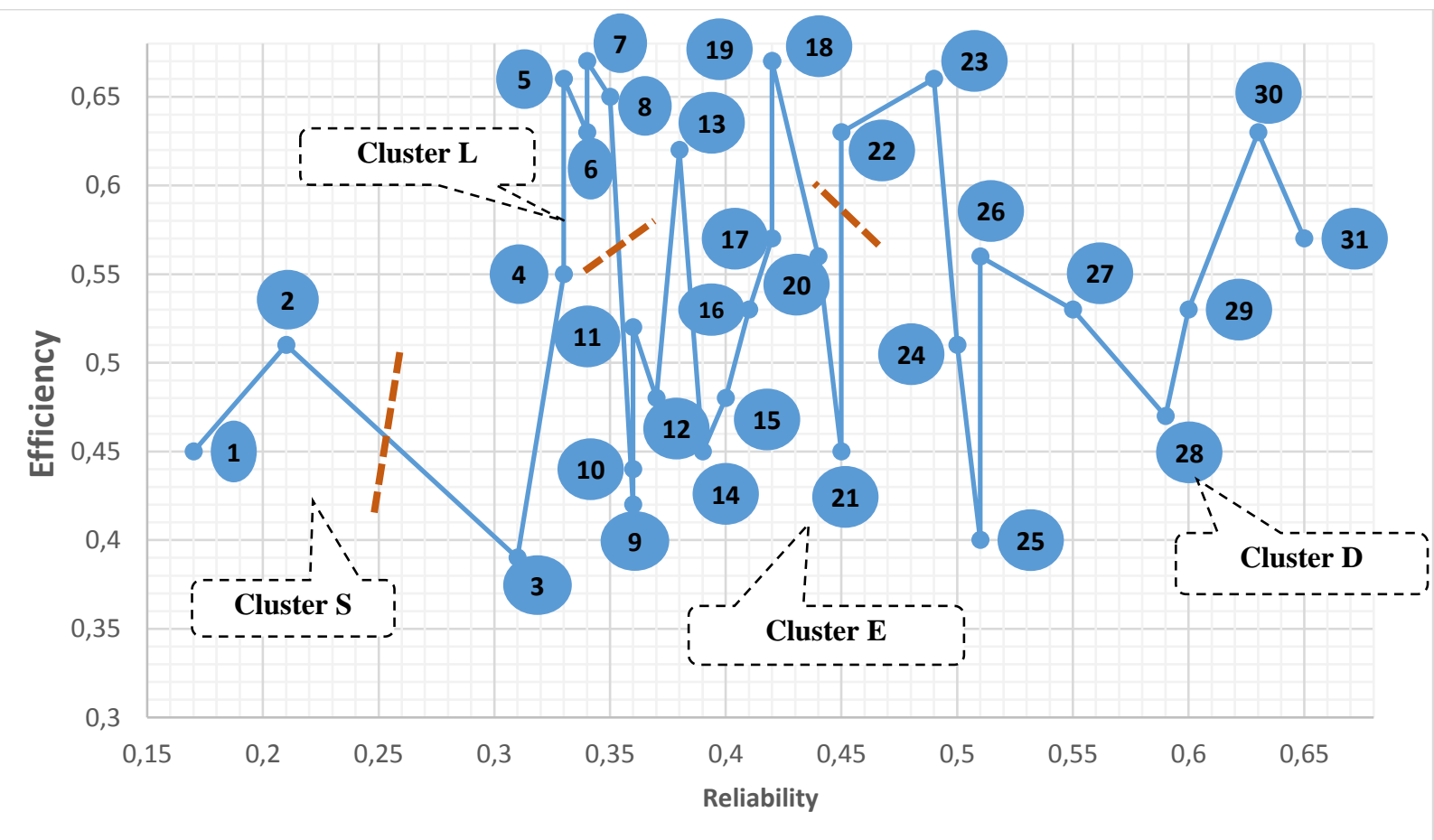

Figure 3 - Spanning tree for the studied

Accordingly to the proposed matrix to the suppliers of D cluster should be given priority attention as they provide retailers receive goods which form the first positive financial performance and image retailer, with them it should proceed to the conclusion of long-term cooperation agreements, and they also should expect retailer where strategic focus and 
diversification of activities and strategic partnerships. The suppliers of cluster E is less "profitable" from this point of view, but retailers should conduct their constant monitoring and seek opportunities to transfer them to the cluster D (both in terms of finding new goods they have to offer, and in terms of concluding contracts on more favorable terms). Relationships with suppliers of cluster $L$ for the retail business is quite problematic in terms of efficiency, under this contracts with them should be short and only on those goods and supplies which cannot be achieved through the involvement of enterprises in the first two clusters. Cooperation with suppliers of cluster L should be reduced to a minimum in the short term and in the long run it should be avoided.

Conclusions. The proposed system of evaluation suppliers in terms of the formation of inventory of trade enterprise is an effective and feasible for use, as it provides an opportunity for suppliers to clustering complex system of coefficients and on this basis to recommend the company to a trade policy of engagement with each individual supplier.

\section{ЛІТЕРАТУРА}

1. Жук O.I. Оцінка рівня ефективності маркетингової діяльності URL:

підприємства. URL: http://archive.nbuv.gov.ua/portal/Soc_Gum/VAPSV/2011_4/St_9.p df.

2. Лиса С. Методичні підходи до оцінювання логістичних ланцюгів торговельних мереж. Вісник КНТЕУ. 2014. № 4. C.56-63.

3. Попов I.B. Обгрунтування вибору потенційного постачальника як фактора підвищення стійкості підприємства.

1. Zhuk O.I. Ocinka rivnja efektyvnosti marketynghovoji dijaljnosti pidpryjemstva.

[Assessment of the level of effectiveness of marketing activity of the enterprise]. Retrieved from: ttp://archive.nbuv.gov.ua/portal/Soc_Gum/VAPSV/2011_4/St_9.p df.

2. Lysa S. (2014) Metodychni pidkhody do ocinjuvannja loghistychnykh lancjughiv torghoveljnykh merezh [Methodical approaches to the evaluation of logistic chains of retail chains]. Visnyk KNTEU, (4), 56-63.

3. Popov I.V. (2010) Obghruntuvannja vyboru potencijnogho postachaljnyka jak faktora pidvyshhennja stijkosti pidpryjemstva. [Substantiation of choice of potential supplier as a factor of increase
http://archive.nbuv.gov.ua/portal/natural/Vnulp/Logistyka/72.pdf.

4. Усков О.Р. Моделювання процесів підтримки рішень вибору постачальника підприємства. Логістика: теорія та практика. 2012. №2(3). С.80-88.

5. Черепов В. Вибір постачальників товарів торговельним підприємством. Товари і ринки. 2016. №1. С. 23-29.

6. Шот А.П. Логістичні рішення у виборі постачальника. URL: http://archive.nbuv.gov.ua/portal/natural/Vnulp/Logistyka/53.pdf.

REFERENCES

of firm stability]. Retrieved from: http://archive.nbuv.gov.ua/portal/natural/Vnulp/Logistyka/72.pdf.

4. Uskov O.R. (2012) Modeljuvannja procesiv pidtrymky rishenj vyboru postachaljnyka pidpryjemstva [Modeling of processes of support of decisions of the choice of the enterprise supplier]. Loghistyka: teorija ta praktyka, (2(3)), 80-88.

5. Cherepov V. (2016) Vybir postachaljnykiv tovariv torghoveljnym pidpryjemstvom.[Selection of suppliers of goods by trading company]. Tovary i rynky, (1), 23-29.

6. Shot A.P. Loghistychni rishennja u vybori postachaljnyka. [Logistics decisions in the selection of the supplier]. Retrieved from:

http://archive.nbuv.gov.ua/portal/natural/Vnulp/Logistyka/53.pdf. 